\title{
DETERMINAN KUALITAS LAPORAN KEUANGAN PEMERINTAH DAERAH SATUAN KERJA PERANGKAT DAERAH KOTA MAKASSAR
}

\author{
Muhammad Tharmizi Junaid \\ Universitas Borneo Tarakan \\ tharmizi.blenk@gmail.com
}

QUALITY DETERMINANTS OF THE GOVERNMENT FINANCIAL STATEMENTS WORKING DEVELOPMENT UNITS, MAKASSAR CITY

\begin{abstract}
Abstrak: Berdasarkan hasil pemeriksaan atas Laporan Keuangan Pemerintah Daerah Kota Makassar TA 2014, BPK memberikan opini "Wajar Dengan Pengecualian" hal ini menunjukkan belum ada peningkatan opini dibandingkan tahun sebelum-sebelumnya. Sebagaimana telah tercantum dalam IHPS BPK RI tahun 2014 Untuk pemerintah kota Makassar secara 5 tahun berturut-turut memperoleh opini WDP Penulis menggunakan pendekatan kuantitatif untuk menjawab permasalahan tersebut menggunakan data primer dalam bentuk kuesioner. Populasi dalam penelitian ini adalah pejabat struktural dan aparat yang melaksanakan fungsi akuntansi atau tata usaha keuangan pada Satuan Kerja Perangkat Daerah di kota Makassar. Sebelum melakukan analisis data, peneliti melakukan uji validitas dan reliabilitas terhadap 81 responden untuk menunjukkan sejauh mana kuesioner tersebut dapat dipercaya dan diandalkan. Teknik analisis data yang digunakan dalam penelitian ini adalah teknik analisis regresi berganda. Hasil dari pengujian hipotesis di dalam penelitian ini menunjukkan bahwa pengawasan intern, kualitas sumber daya manusia, dan penerapan akrual basis berpengaruh secara positif dan signifikan terhadap kualitas laporan keuangan pemerintah daerah.
\end{abstract}

Kata kunci: Pengawasan Intern, Kualitas Sumber Daya Manusia, Penerapan Akrual Basis, dan Kualitas Laporan Keuangan Pemerintah Daerah.

Abstract : Based on the results of the examination of the 2014 Makassar City Government Financial Report, the BPK gave a "Fair With Exceptions" opinion, indicating that there has been no increase in opinion compared to the previous year. As already stated in the 2014 BPK RI IHPS For the Makassar city government, in 5 years in a row obtained WDP opinion. The author uses a quantitative approach to answer these problems using primary data in the form of questionnaires. The population in this study are structural officials and officials who carry out the functions of accounting or financial administration at the Regional Work Unit in Makassar. Before conducting data analysis, researchers conducted a validity and reliability test of 81 respondents to show the extent to which the questionnaire was reliable and reliable. Data analysis technique used in this study is multiple regression analysis techniques. The results of testing the hypothesis in this study indicate that internal control, the quality of human 
resources, and the application of accrual basis have a positive and significant effect on the quality of local government financial reports.

\section{Key Words: Internal Controlling, Quality Of Human Resources, Application Of Accrual Bases, And Quality Of Local Government Financial Statements.}

\section{LATAR BELAKANG}

Negara Indonesia mempunyai suatu Pemerintahan yang berfungsi sebagai kesatuan organisasi. Pemerintahan pusat maupun Pemerintahan daerah mengemban amanat untuk menjalankan tugas Pemerintahan melalui peraturan perundang-undangan. Untuk menyelenggarakan Pemerintahan, Pemerintah memungut berbagai macam jenis pendapatan dari rakyat yang digunakan untuk penyelenggaraan Pemerintah dalam rangka pelayanan kepada rakyat, pelaksanaan pembangunan, dan banyak kegiatan yang harus dilaksanakan. Untuk dapat melaksanakan tujuan tersebut Pemerintah Daerah diberi wewenang untuk melaksanakan urusan pembangunan sebagai urusan rumah tangganya sendiri yang disebut otonomi. Sebagaimana yang dimaksudkan di dalam Undangundang No.22 tahun 1999 yang diamandemen dengan UndangUndang Nomor 32 Tahun 2004 tentang otonomi daerah dan UndangUndang No. 25 tahun 1999 tentang perimbangan keuangan pusat dan daerah. Salah satu wewenang yang menjadi urusan rumah tangganya sendiri adalah bidang Keuangan Daerah. Pengurus keuangan ini diantaranya adalah penyelenggaraan penyusunan pertanggungjawaban dan pengawasan Keuangan Daerah sebagaimana yang dimaksud di dalam Peraturan Pemerintah No. 58 tahun 2005.

Undang-Undang ini telah melahirkan paradigma baru dalam pelaksanaan otonomi daerah, yang meletakkan otonomi yang penuh, luas dan bertanggung jawab pada daerah. Penyelenggaraan pemerintah daerah dengan berdasarkan undangundang tersebut juga melahirkan nuansa baru, yaitu pergeseran kewenangan pemerintahan yang desentralistik partipatoris (Mardiasmo, 2006).

Fenomena yang menjadi sorotan utama pada organisasi sektor publik di Indonesia saat ini adalah menguatnya tuntutan akuntabilitas dan transparansi atas lembagalembaga publik baik di pusat maupun di daerah. Dalam konteks organisasi pemerintahan, akuntabilitas publik dapat dikatakan sebagai suatu bentuk pemberian informasi dan disclosure atas aktivitas dan kinerja finansial pemerintah kepada pihak-pihak yang berkepentingan dengan informasi tersebut.

Akuntabilitas juga dapat diartikan sebagai sebuah bentuk kewajiban mempertanggungjawabkan keberhasilan atau kegagalan pelaksanaan misi organisasi dalam mencapai tujuan dan sasaran yang telah ditetapkan sebelumnya melalui suatu media pertanggungjawaban yang dilaksanakan secara periodik. Selain 
itu, Governmental Accounting Standard Board (GASB) dalam Statement of Financial Accounting Concepts (SFAC) No.1 tentang Objectives of Financial Reporting menyatakan bahwa akuntabilitas merupakan dasar pelaporan keuangan di organisasi pemerintahan.

Perihal tuntutan akuntabilitas dan transparansi sektor publik, dalam UU No.17/2003 pasal 30 dijelaskan bahwa pemerintah daerah diharuskan menyampaikan laporan keuangan sebagai bentuk pertanggungjawaban pelaksanaan Anggaran Pendapatan dan Belanja Daerah (APBD) kepada Dewan Perwakilan Rakyat Daerah (DPRD). Menurut Permendagri No.13/2006, laporan keuangan yang dimaksud setidaknya meliputi Laporan Realisasi Anggaran, Neraca, Laporan Arus Kas dan Catatan atas Laporan Keuangan. Secara umum, laporan keuangan diartikan sebagai catatan atas informasi keuangan suatu perusahaan pada suatu periode akuntansi yang dapat digunakan untuk menggambarkan kinerja perusahaan tersebut (SAK, 2009). Menurut Pernyataan Standar Akuntansi Keuangan (PSAK) No.1/2009, tujuan laporan keuangan adalah menyediakan informasi yang menyangkut posisi keuangan, kinerja serta perubahan posisi keuangan suatu perusahaan yang bermanfaat bagi sejumlah besar pemakai dalam pengambilan keputusan. Namun demikian, laporan keuangan tidak menyediakan semua informasi yang mungkin dibutuhkan pemakai dalam mengambil keputusan ekonomi karena hanya secara umum menggambarkan pengaruh keuangan pada kejadian masa lalu.
Penyusunan laporan keuangan diharapkan kepada pelaku akuntansi agar berpedoman pada standar akuntansi yang telah ditentukan yang dalam hal ini yaitu Standar Akuntansi Pemerintahan (SAP). Berdasarkan PP No.71/2010 menyebutkan bahwa standar akuntansi pemerintahan merupakan pedoman di dalam menyusun dan menyajikan laporan keuangan. Standar akuntansi pemerintahan adalah syarat mutlak yang harus dijadikan pedoman agar kualitas laporan keuangan di Indonesia dapat ditingkatkan. Selain itu, dalam penyusunan laporan keuangan juga diperlukan sistem akuntansi yang memadai. Sistem akuntansi yang memadai akan menghasilkan aktivitas keuangan yang terstruktur, tepat dan akuntabel sehingga berdampak pada laporan keuangan yang dihasilkan akan memenuhi karakteristik kualitatif.

Fenomena terbaru saat ini adalah saat Kepala Perwakilan BPK Provinsi Sulawesi Selatan, Tri Heriadi, dalam sambutannya pada acara penyerahan Laporan Hasil Pemeriksaan BPK, Pemeriksaan BPK atas Laporan Keuangan Pemerintah Daerah dilakukan dalam rangka memberikan pendapat/opini atas kewajaran informasi keuangan yang disajikan dalam laporan keuangan dengan mendasarkan pada, kesesuaian dengan standar akuntansi pemerintahan, kecukupan pengungkapan, kepatuhan terhadap perundang-undangan dan efektivitas sistem pengendalian intern. Dalam melaksanakan pemeriksaan keuangan, selain memberikan opini atas laporan keuangan, BPK juga melaporkan hasil pemeriksaan atas 
sistem pengendalian intern, dan laporan hasil pemeriksaan atas kepatuhan terhadap peraturan peundang-undangan. Berdasarkan hasil pemeriksaan atas Laporan Keuangan Pemerintah Daerah Kota Makassar TA 2014, BPK memberikan opini “ Wajar Dengan Pengecualian " hal ini menunjukkan belum ada peningkatan opini dibandingkan tahun sebelumsebelumnya. Sebagaimana telah tercantum dalam IHPS BPK RI tahun 2014 untuk pemerintah kota Makassar secara 5 tahun berturutturut memperoleh opini WDP. Lemahnya pengawasan dan kurang jelasnya pengelolaan asset pemerintah dijadikan dasar oleh BPK dalam mengeluarkan opini tersebut. Terkhusus pada tahun 2014 permasalahannya pada pengelolaan asset yang nilainya sebesar $\mathrm{Rp}$ 346,42 miliyar yang tidak dapat diyakini kewajarannya.

Hal tersebut menggambarkan bahwa kinerja Pemerintah daerah belum dinyatakan baik, dalam hal ini tata kelola laporan keuangan, oleh karena itu dilakukannya pengawasan intern dan sistem akuntansi keuangan yang baik dapat menggambarkan bagaimana kinerja Pemerintah daerah untuk menunjukan pencapaian hasil yang dicapai. Kualitas SDM juga perlu diperbaiki, sebab tanpa andil dari para pembuat tentu tidak akan menghasilkan sebuah laporan yang berkualitas. Oleh karena itu selain pengawasan yang efektif, dibutuhkan juga sumber daya manusia yang berkompeten, serta adanya sebuah peraturan baru yaituu PP No 71 tahun 2010 tentang penerapan akrual basis diharap mampu menjawab semua pertanyaan yang ada.

\section{PERUMUSAN MASALAH}

Berdasarkan latar belakang yang dikemukakan, maka rumusan masalah dalam penelitian ini adalah:

1. Apakah pengawasan intern berpengaruh terhadap kualitas laporan keuangan pemerintah daerah?

2. Apakah kualitas sumber daya manusia berpengaruh terhadap kualitas laporan keuangan pemerintah daerah?

3. Apakah penerapan akrual basis berpengaruh terhadap kualitas laporan keuangan pemerintah daerah?

\section{TUJUAN PENELITIAN}

Tujuan penelitian ini adalah memberi jawaban atas pertanyaan penelitian yang ada, yang menjadi tujuan penelitian, antara lain:

1. Untuk mengetahui pengaruh pengawasan internal terhadap kualitas laporan keuangan pemerintah daerah.

2. Untuk mengetahui pegaruh kualitas SDM terhadap kualitas laporan keuangan pemerintah daerah.

3. Untuk mengetahui pengaruh penerapan Akrual Basis terhadap kualitas laporan keuangan pemerintah daerah. 


\section{TINJAUAN PUSTAKA}

\begin{tabular}{ll} 
Teori & Kegunaan-Keputusan \\
\hline Informasi & (Decision-Usefulness \\
\hline Theory) &
\end{tabular}

Sejak tahun 1954 telah dikenal Teori kegunaan-keputusan (decisionusefulness theory) informasi akuntansi, dan menurut Staubus (2000) dalam Kiswara (2011) telah menjadi referensi dari penyusunan kerangka konseptual Financial Accounting Standard Boards (FASB), yaitu Statement of Financial Accounting Concepts (SFAC) yang berlaku di Amerika Serikat. Pada tahap awal, teori ini dikenal dengan nama lain yaitu $a$ theory of accounting to investors.

Dalam hal ini Teori kegunaankeputusan (decision-usefulness theory) informasi akuntansi mengandung komponen-komponen yang perlu dipertimbangkan oleh para penyaji informasi akuntansi agar cakupan yang ada dalam suatu laporan keuangan dapat memenuhi kebutuhan para pengambil keputusan yang akan menggunakannya. SFAC No.2 tentang Qualitative Characteristics of Accounting Information menggambarkan hirarki dari kualitas informasi akuntansi dalam bentuk kualitas primer, kandungannya dan kualitas sekunder. Kualitas primer dari informasi yang berguna dalam pengambilan keputusan ekonomi adalah nilai relevan dan nilai reliabilita. Nilai relevan dan reliabilitas adalah dua kualitas utama yang membuat informasi akuntansi yang berguna dalam pengambilan keputusan.

Kandungan kualitas primer kegunaan-keputusan informasi akuntansi meliputi komponenkomponen kandungan dari nilai relevan, yaitu ketepatwaktuan (timeliness), Nilai umpan balik (feedback Value) dan nilai prediktif (predictive-value) dan komponenkomponen kandungan reliabilitas, yaitu menggambarkan yang senyatanya (representaation faithfullness), netralitas (neutralitas) dan dapat diperiksa (verifiability). Selain itu juga terdapat kualitas sekunder, sebagai penghubung kualitas primer, yaitu komparabilitas (comparability) dan taat asas (consistency).

\section{Pengawasan Intern}

Terdapat dua ketetapan MPR (Majelis Permusyawaratan Rakyat) yang menggariskan bahwa dipandang perlu untuk memberdayakan pengawasan oleh lembaga Negara, lembaga politik dan kemasyarakatan. Hal ini dihubungkan oleh adanya ketetapan Majelis Permusyawaratan Rakyat Nomor X/MPR/1998 tentang pokokpokok Reformasi Pembangunan dalam rangka Penyelamatan dan Normalisasi Kehidupan Nasional sebagai haluan Negara, dan Ketetapan Nomor XI/MPR/1998 tentang penyelenggaraan Negara yang Bersih dan Bebas Korupsi, Kolusi, dan Nepotisme, maka peran dan fungsi pengawasan, pengadilan dan pemeriksaan menjadi sangat strategis.

Banyak kasus disebuah perusahaan atau organisasi tidak dapat menyelesaikan seluruhnya karena tidak ditepati waktu penyelesaian, anggaran berlebihan dan kegiatan yang lain menyimpang 
dari rencana semula maka disini dibutuhkan suatu fungsi pengawasan antara pengawasan dan pemrosesan merupakan hal yang sangat erat sekali. Pengawasan merupakan hal penting dalam suatu organisasi. Pengawasan dilakukan dalam upaya untuk meyakinkan bahwa implementasi suatu kebijakan telah sesuai dengan yang diharapkan. Hakikat pengawasan adalah mencegah sedini mungkin terjadinya penyimpangan, pemborosan, penyelewengan, hambatan, kesalahan dan kegagalan, dalam mencapai tujuan dan pelaksanaan tugas-tugas organisasi.

Menurut PP No. 60 Tahun 2008 tentang Sistem Pengendalian Intern Pemerintah Menyebutkan bahwa Pengawasan intern adalah seluruh proses kegiatan, review, evaluasi, pemantauan, dan kegiatan pengawasan lain terhadap penyelenggaran tugas dan fungsi organisasi dalam rangka memberikan keyakinan yang memadai bahwa kegiatan telah dilaksankaan sesuai dengan tolak ukur yang telah ditetapkan secara efektif dan efisien untuk kepentingan pemimin dalam mewujudkan tata kepemerintahan yang baik.

Pengawasan ini dilaksanakan oleh aparat pengawasan secara intern, dengan tujuan untuk tercapainya efektifitas dan efesiensi kegiatan, keandalan laporan keuangan (realisasi anggaran di sektor pemerintahan), serta ketaatan dengan peraturan yang berlaku. Pengawasan intern di daerah dilakukan oleh inspektorat pada daerah tersebut yang melakukan pengawasan terhadap jalannya pemerintahan daerah. Pengawasan
Intern merupakan langkah sistem atau alat yang menyediakan jaminan atas keberhasilan sasaran kinerja suatu kegiatan (Halim 2007). Pengawasan Intern adalah sebagai berikut: Kegiatan pengawasan yang dilakukan oleh pemimpin atau manajer puncak dan atau pimpinan atau manajer unit satuan kerja dilingkungan organisasi dan unit atau satuan kerja masing-masing (Nawawi 2000)

\section{Kualitas Sumber Daya Manusia}

Kata kualitas sering digunakan ketika kita berbicara tentang peningkatan kemampuan seseorang, ketika kita memperoleh sertifikasi, mengikuti pelatihan atau mengikuti pendidikan. Dalam pengertian yang lebih luas, yang sekarang digunakan dalam pembangunan masyarakat, kualitas tidak hanya berkaitan dengan keterampilan dan kemampuan individu, tetapi juga dengan kemampuan organisasi untuk mencapai misinya secara efektif dan kemampuan mempertahankan kelangsungan hidupnya dalam jangka panjang (Sari 2014).

Kualitas sumber daya manusia adalah kemampuan sumber daya manusia untuk melaksanakan tugas dan tanggung jawab yang diberikan kepadanya dengan bekal pendidikan, pelatihan, dan pengalaman yang cukup memadai. Sumber daya manusia merupakan pilar penyangga utama sekaligus penggerak roda organisasi dalam usaha mewujudkan visi dan misi serta tujuan dari organisasi tersebut. Sumber daya manusia merupakan salah satu elemen organisasi yang sangat penting, oleh karena itu harus 
dipastikan bahwa pengelolaan sumber daya manusia dilakukan sebaik mungkin agar mampu memberikan kontribusi secara optimal dalam upaya pencapaian tujuan organisasi.

Kompetensi adalah ciri seseorang yang dapat dilihat dari keterampilan, pengetahuan, dan kemampuan yang dimilikinya dalam hal menyelesaikan tugas-tugas yang dibebankan kepadanya (Hervesi, 2005 dalam Indriasari 2008). Kompetensi merupakan dasar seseorang untuk mecapai kinerja tinggi dalam menyelesaikan kinerjanya. Sumber daya manusia yang tidak memiliki kompetensi tidak akan dapat menyelesaikan pekerjaanya secara efisien, efektif, dan ekonomis. Dalam hal ini pekerjaan yang dihasilkan tidak akan tepat waktu dan terdapat pemborosan waktu serta tenaga. Dengan adanya kompetensi sumber daya manusia maka waktu pembuatan laporan keuangan akan dapat dihemat. Hal ini karena sumber daya manusia tersebut telah memiliki pengetahuan dan pemahaman mengenai hal-hal yang harus dikerjakan, sehingga laporan keuangan yang disusun dapat diselesaikan dan disajikan tepat pada waktunya. Semakin cepat laporan keuangan disajikan maka akan semakin baik dalam hal pengambilan keputusan (Mardiasmo 2002).

\section{Penerapan Akrual Basis}

Basis akuntansi akrual, seperti yang telah disimpulkan oleh KSAP (2006:3), adalah suatu basis akuntansi di mana transaksi ekonomi dan peristiwa lainnya diakui, dicatat, dan disajikan dalam laporan keuangan pada saat terjadinya transaksi tersebut, tanpa memerhatikan waktu kas atau setara kas diterima atau dibayarkan. Selanjutnya, dalam makalah yang sama, KSAP menyatakan bahwa dalam akuntansi berbasis akrual, waktu pencatatan (recording) sesuai dengan saat terjadinya arus sumber daya, sehingga dapat menyediakan informasi yang paling komprehensif karena seluruh arus sumber daya dicatat. Dapat disimpulkan bahwa basis akrual mampu memenuhi tujuan pelaporan yang tidak dapat dipenuhi oleh basis kas, tujuan pelaporan tersebut adalah tujuan manajerial dan pengawasan.

Kualitas Laporan Keuangan $\underline{\text { Pemerintah Daerah }}$

Laporan keuangan merupakan produk akhir dari sistem akuntansi yang berlaku pada suatu organisasi, baik organisasi swasta maupun pada organisasi pemerintahan. Laporan keuangan pada organisasi pemerintahan merupakan asersi dari pihak manajemen pemerintah yang menginformasikan kepada pihak lain (stakeholder) tentang kondisi keuangan pemerintah. Di Indonesia, laporan keuangan pokok yang harus dibuat oleh pemerintah sebagaimana tercantum dalam pasal 30, UU No.17/2003 tentang keuangan negara meliputi laporan realisasi APBN/D, neraca, laporan arus kas dan catatan atas laporan keuangan.

Tujuan laporan keuangan penting baik pada organisasi swasta maupun pada pemerintahan sehingga pemerintah perlu memperhatikan kualitas dari laporan keuangan tersebut. Kualitas merupakan sesuatu 
yang memenuhi atau melebihi harapan ataupun kriteria yang telah ditetapkan. Kriteria untuk menilai kualitas laporan keuangan menurut PP No.71/2010 tentang Standar Akuntansi Pemerintah Indonesia adalah dapat dipahami, relevan, andal dan dapat dibandingkan.

Kriteria tersebut di atas merujuk pada informasi yang disajikan dalam laporan keuangan. Kualitas laporan keuangan akan meningkatkan kualitas informasi yang disajikan dalam laporan keuangan. Para pengguna laporan keuangan yakin dalam mengambil keputusan karena didasarkan pada informasi yang telah dipersiapkan dengan baik, disetujui dan diaudit secara transparan, dapat dipertanggungjawabkan dan berkualitas. Pendapat tersebut menunjukkan bahwa kualitas laporan keuangan adalah sejauh mana laporan keuangan menyajikan informasi yang benar dan jujur. Hal ini berarti bahwa kualitas laporan keuangan menunjukkan konsep kualitas informasi dari laporan tersebut.

Berdasarkan PP No.71/2010
tentang Standar Akuntansi
Pemerintahan mengenai kualitas
laporan keuangan pemerintah daerah
seperti yang telah dijelaskan
sebelumnya bahwa karakteristik
kualitatif laporan keuangan
merupakan ukuran-ukuran normatif
yang perlu diwujudkan dalam
informasi akuntansi sehingga dapat
memenuhi tujuannya. Adapun empat
karakteristik berikut ini merupakan
prasyarat normatif yang diperlukan
agar laporan keuangan pemerintah
dapat memenuhi kualitas yang
dikehendaki, yaitu:

1. Relevan

Laporan keuangan bisa dikatakan relevan apabila informasi yang termuat di dalamnya dapat mempengaruhi keputusan pengguna dengan membantu mereka mengevaluasi peristiwa masa lalu atau masa kini dan memprediksi masa depan serta menegaskan atau mengoreksi hasil evaluasi mereka di masa lalu. Dengan demikian informasi laporan keuangan yang relevan dapat dihubungkan dengan maksud penggunaannya.

2. Andal

Informasi dalam laporan keuangan bebas dari pengertian yang menyesatkan dan kesalahan material, menyajikan setiap fakta secara jujur, serta dapat diverifikasi. Informasi mungkin relevan, tetapi jika hakikat atau penyajiannya tidak dapat diandalkan maka penggunaan informasi tersebut secara potensial dapat menyesatkan.

3. Dapat dibandingkan

Informasi yang termuat dalam laporan keuangan akan lebih berguna jika dapat dibandingkan dengan laporan keuangan periode sebelumnya atau laporan keuangan entitas pelaporan lain pada umumnya. Perbandingan dapat dilakukan secara internal dan eksternal. Perbandingan secara internal dapat dilakukan bila suatu entitas menerapkan kebijakan akuntansi yang sama dari tahun ke tahun. Perbandingan secara eksternal dapat dilakukan bila entitas yang diperbandingkan menerapkan kebijakan akuntansi yang sama. Apabila entitas pemerintah akan menerapkan kebijakan akuntansi yang lebih baik 
daripada kebijakan akuntansi yang sekarang diterapkan, perubahan tersebut diungkapkan pada periode terjadinya perubahan.

4. Dapat dipahami

Informasi yang disajikan dalam laporan keuangan dapat dipahami oleh pengguna dan dinyatakan dalam bentuk serta istilah yang disesuaikan dengan batas pemahaman para pengguna. Untuk itu, pengguna diasumsikan memiliki pengetahuan yang memadai atas kegiatan dan lingkungan operasi entitas pelaporan, serta adanya kemauan pengguna untuk mempelajari informasi yang dimaksud.

\section{Hipotesis}

Adapun hipotesis dalam penelitian adalah:

1. Pengawasan intern berpengaruh positif dan signifikan terhadap kualitas laporan keuangan pemerintah daerah

2. Kualitas sumber daya manusia berpengaruh positif dan signifikan terhadap kualitas laporan keuangan pemerintah daerah

3. Penerapan akrual basis berpengaruh positif dan signifikan terhadap kualitas laporan keuangan pemerintah daerah.

\section{METODOLOGI PENELITIAN}

Penelitian ini merupakan jenis penelitian kuantitatif. Indriantoro dan Bambang Supomo (2014: 12) mengemukakan bahwa paradigma penelitian kuantitatif menekankan pada pengujian teori-teori melalui pengukuran variabel-variabel penelitian dengan angka dan melakukan analisis data dengan prosedur statistik. Lokasi penelitian dilakukan di beberapa kantor SKPD yang berada di kota Makassar. Peneliti memilih lokasi tersebut, karena dianggap mampu untuk merepresentasikan bagaimana kualitas laporan keuangan pemerintah daerah khususnya pemerintah kota Makassar.

Dalam penelitian ini menggunakan pendekatan penelitian deskriptif, penelitian deskriptif merupakan penelitian terhadap fenomena atau populasi tertentu yang diperoleh peneliti dari subyek berupa: individu, organisasi, industri atau perspektif yang lain. Tujuan penelitian deskriptif ini adalah untuk menguji hipotesis atau menjawab pertanyaan yang berkaitan dengan current status dari subjek yang diteliti. Tipe penelitian ini umumnya berkaitan dengan opini (individu, kelompok atau organisasi), kejadian atau prosedur.

Populasi adalah wilayah generalisasi yang terdiri dari objek atau subjek yang akan menjadi kuantitas dan karakteristik tertentu yang ditetapkan oleh penelitian untuk dipelajari dan kemudian ditarik kesimpulannya menurut Sugiono (2002:43). Populasi dalam penelitian ini adalah pengelola unit kerja atau pejabat struktural dan aparat yang terlibat dalam proses pembuatan laporan keuangan pada Satuan Kerja Perangkat Daerah (SKPD) Kota Makassar. Jumlah SKPD di kota Makassar sebanyak 50 SKPD yang terdiri dari 19 Dinas, 8 Badan, 2 Kantor, 2 sekertariat, 7 Perusahaan Daerah, RSUD, Inspektorat, dan 14 kecamatan. 
Metode pengumpulan data menggunakan kuesioner dari sumber primer, yaitu sumber data yang langsung memberikan data pada pengumpul data (Sugiyono, 2011:308) untuk diperoleh data yang relevan, dapat dipercaya, obyektif dan dapat dijadikan landasan dalam proses analisis. Prosedur pengumpulan tersebut digunakan untuk memperoleh informasi mengenai variabel penelitian yaitu penerapan sistem akuntansi keuangan daerah, kompetensi sumber daya manusia, sistem pengendalian internal, kemampuan manajemen serta kualitas laporan keuangan pemerintah daerah. Penyebaran kuesioner dilakukan dengan cara penyebaran langsung kepada sampel penelitian yaitu pejabat struktural dan aparat yang melaksanakan fungsi akuntansi atau tata usaha keuangan pada Satuan Kerja Perangkat Daerah (SKPD) Kota Makassar.

Jenis instrument penelitian dalam penelitian ini adalah kuesioner. Kuesioner adalah sejumlah pertanyaan tertulis yang digunakan untuk memperoleh informasi dari responden dalam arti tentang pribadinya, atau hal-hal yang ia ketahui. Kemudian data diukur dengan menggunakan skala Likert. Skala Likert merupakan metode yang mengukur sikap dengan menyatakan setuju atau ketidaksetujuannya terhadap subyek, obyek atau kejadian tertentu. Skala ini umumnya mengggunakan lima angka penilaian, yaitu: (1) sangat setuju, (2) setuju, (3) tidak pasti atau netral, (4) tidak setuju, (5) sangat tidak setuju. Jenis data penelitian ini berupa data primer dan data sekunder. Data primer yaitu data penelitian yang diperoleh atau dikumpulkan langsung dari sumber asli (tanpa perantara) berupa jawaban atas kuesioner yang dibagikan kepada responden pada objek penelitian sedangkan data sekunder adalah data penelitian yang diperoleh atau dikumpulkan melalui perantara pihak ketiga berupa daftar referensi studi pustaka, website pemerintah, dokumen perundangundangan dan lain-lain.

\section{$\underline{\text { Uji Hipotesis }}$}

1. $\mathrm{Uji} F$

Uji F digunakan untuk mengetahui apakah variabel-variabel independen secara simultan berpengaruh signifikan terhadap variabel dependen. Derajat kepercayaan yang digunakan adalah 0,05 . Apabila nilai $F$ hasil perhitungan lebih besar daripada nilai $\mathrm{F}$ menurut tabel maka hipotesis alternatif, yang menyatakan bahwa semua variabel independen secara simultan berpengaruh signifikan terhadap variabel dependen.

\section{Uji t}

Uji $\mathrm{t}$ digunakan untuk mengetahui apakah variabel-variabel independen secara parsial berpengaruh nyata atau tidak terhadap variabel dependen. Derajat

Model Summary

\begin{tabular}{|l|r|r|r|r|}
\hline $\begin{array}{l}\text { Mode } \\
1\end{array}$ & $\mathrm{R}$ & $\begin{array}{c}\mathrm{R} \\
\text { Square }\end{array}$ & $\begin{array}{r}\text { Adjuste } \\
\mathrm{d} \mathrm{R} \\
\text { Square }\end{array}$ & $\begin{array}{c}\text { Std. Error } \\
\text { of the } \\
\text { Estimate }\end{array}$ \\
\hline 1 & $\begin{array}{r}, 792 \\
\mathrm{a}\end{array}$ &, 628 &, 613 & 2,831 \\
\hline
\end{tabular}

a. Predictors: (Constant), X3, X1, X2 
signifikansi yang digunakan adalah 0,05 . Apabila nilai signifikan lebih kecil dari derajat kepercayaan maka kita menerima hipotesis alternatif, yang menyatakan bahwa suatu variabel independen secara parsial mempengaruhi variabel dependen.

\section{HASIL DAN PEMBAHASAN}

$\underline{\text { Hasil }}$

Uji Validitas adalah prosedur untuk memastikan apakah kuesioner yang akan dipakai untuk mengukur variabel penelitian valid atau tidak. Kuesioner dapat dikatakan valid jika pernyataan pada kuesioner mampu untuk mengungkapkan sesuatu yang diukur oleh kuesioner tersebut. Untuk mengetahui item pernyataan itu valid dengan melihat nilai Corrected Item Total Corelation. Apabila item pernyataan mempunyai $\mathrm{r}$ hitung > dari $\mathrm{r}$ tabel maka dapat dikatakan valid. Pada penelitian ini terdapat jumlah sampel $(n)=81$ responden dan besarnya df dapat dihitung $81-2=79$ dengan $\mathrm{df}=79$ dan alpha $=0,05$ didapat $\mathrm{r}$ tabel $=$ 0,218 (sumber: lampiran tabel 15, Ghozali, 2013). Jadi, item pernyataan yang valid mempunyai $r$ hitung lebih besar dari 0,218.

Konsep reliabilitas dapat dipahami melalui ide dasar konsep tersebut yaitu konsistensi. Peneliti dapat mengevaluasi instrumen penelitian berdasarkan perspektif dan teknik yang berbeda, tetapi pertanyaan mendasar untuk mengukur reliabilitas data adalah bagaimana konsistensi data yang dikumpulkan. Pengukuran reliabilitas menggunakan indeks numerik yang disebut dengan koefisien. Konsep reliabilitas dapat diukur melalui tiga pendekatan yaitu koefisisen stabilitas, koefisien ekuivalensi dan reliabilitas konsistensi internal. Uji reliabilitas merupakan alat ukur untuk mengukur suatu kuesioner yang merupakan indikator dari variabel. Suatu kuesioner dikatakan reliabel jika jawaban dari responden itu stabil dari waktu ke waktu. Kriteria suatu instrumen penelitian dikatakan realibel jika dengan menggunakan uji statistik Cronbach Alpha $(\alpha)$, koefisien realibilitas > 0,60 .

Berdasarkan tabel diatas nilai $\mathrm{R}$ adalah 0,792 menurut pedoman interpretasi koefisien korelasi, angka ini termasuk kedalam kategori korelasi berpengaruh kuat karena berada pada interval $0,60-0,799$. Hal ini menunjukkan bahwa pengawasan intern, kualitas sumber daya manusia, dan penerapan akrual basis mempunyai pengaruh yang kuat terhadap kualitas laporan keuangan pemerintah daerah. Berdasarkan hasil uji koefisien deteminasi diatas, nilai $\mathrm{R}^{2}$ (Adjusted $R$ Square) dari model regresi digunakan untuk mengetahui seberapa besar kemampuan variabel bebas (independent) dalam menerangkan variabel terikat (dependent). Dari tabel diatas diketahui bahwa nilai $\mathrm{R}^{2}$ sebesar 0,613, hal ini berarti bahwa 61,3\% yang menunjukkan bahwa kualitas laporan keuangan dipengaruhi oleh variabel pengawasan intern, kualitas sumber daya manusia, dan 
penerapan akrual basis. Sisanya sebesar 38,7\% dipengaruhi oleh variabel lain yang belum diteliti dalam penelitian ini.

Uji statistik $F$ pada dasarnya menunjukkan apakah semua variabel independen atau bebas yang dimasukkan dalam model mempunyai pengaruh secara bersama-sama terhadap variabel dependen atau terikat. Uji ini juga berarti bahwa semua variabel independen secara simultan merupakan penjelasan yang signifikan terhadap variabel

\section{ANOVA $^{\mathrm{a}}$}

\begin{tabular}{|c|c|c|c|c|c|}
\hline Model & $\begin{array}{c}\text { Sum of } \\
\text { Square } \\
\text { s }\end{array}$ & df & $\begin{array}{c}\text { Mean } \\
\text { Squar } \\
\mathrm{e}\end{array}$ & $\mathrm{F}$ & Sig. \\
\hline $\begin{array}{ll}1 & \text { Regr } \\
\text { essio }\end{array}$ & 1040,5 & 3 & $\begin{array}{r}346,8 \\
\end{array}$ & $\begin{array}{r}43, \\
283\end{array}$ & $\begin{array}{r}, 00 \\
0^{\mathrm{b}}\end{array}$ \\
\hline $\mathrm{n}$ & & & & & \\
\hline $\begin{array}{l}\text { Resi } \\
\text { dual }\end{array}$ & $\begin{array}{r}617,02 \\
9\end{array}$ & 77 & 8,013 & & \\
\hline $\begin{array}{l}\text { Tota } \\
1\end{array}$ & $\begin{array}{r}1657,5 \\
56\end{array}$ & 80 & & & \\
\hline
\end{tabular}

a. Dependent Variable: Y

b. Predictors: (Constant), X3, X1, X2 dependen.

Berikut adalah tabel hasil pengujian secara simultan:

Pengujian signifikan bertujuan untuk mengetahui signifikansi korelasi pengawasan intern (X1), kualitas sumber daya manusia (X2), dan penerapan akrual basis (X3), secara bersama-sama terhadap kualitas laporan keuangan pemerintah daerah (Y) studi pada Satuan Kerja Perangkat Daerah (SKPD) Kota Makassar. Uji signifikansi dilakukan dengan menggunakan uji F. Berdasarkan hasil uji $F$ diperoleh nilai $F_{\text {hitung }}$

Coefficients $^{\mathrm{a}}$

\begin{tabular}{|c|c|c|c|c|c|}
\hline \multirow[b]{2}{*}{ Model } & \multicolumn{2}{|c|}{$\begin{array}{l}\text { Unstandardize } \\
\text { d Coefficients }\end{array}$} & $\begin{array}{l}\text { Standar } \\
\text { dized } \\
\text { Coeffici } \\
\text { ents }\end{array}$ & \multirow[b]{2}{*}{$\mathrm{t}$} & \multirow[b]{2}{*}{ Sig. } \\
\hline & B & $\begin{array}{l}\text { Std. } \\
\text { Erro } \\
\text { r }\end{array}$ & Beta & & \\
\hline $\begin{array}{l}1 \text { (Const } \\
\text { ant) }\end{array}$ & 5,998 & $\begin{array}{r}4,66 \\
3\end{array}$ & & 1,286 & ,202 \\
\hline $\begin{array}{l}\text { Penga } \\
\text { wasan } \\
\text { Intern }\end{array}$ & ,311 &, 146 & , 184 & 2,136 & ,036 \\
\hline $\begin{array}{l}\text { Kualita } \\
\text { s SDM }\end{array}$ & ,424 &, 112 & ,375 & 3,774 & ,000 \\
\hline $\begin{array}{l}\text { Penera } \\
\text { pan } \\
\text { Akrual } \\
\text { Basis }\end{array}$ & ,818 & ,238 & ,353 & 3,434 & ,001 \\
\hline
\end{tabular}

a. Dependent Variable: Y

sebesar 43,283 sedangkan $F_{\text {tabel }}$ sebesar 2,07. Dapat diketahui bahwa $F_{\text {hitung }}(42,283)>F_{\text {tabel }}(2,07)$ jadi hipotesis diterima. Berdasarkan hasil uji juga diperoleh nilai $P$ value sebesar $0,000^{\mathrm{b}}$ lebih kecil dari 0,05 . Kesimpulannya berarti bahwa secara simultan, pengawasan intern (X1), kualitas sumber daya manusia (X2), dan penerapan akrual basis (X3) berpengaruh positif dan signifikan terhadap kualitas laporan keuangan pemerintah daerah $(\mathrm{Y})$ di SKPD kota Makassar.

Berdasarkan tabel 4.21 diatas dapat dianalisis model estimasi sebagai berikut:

$\mathrm{Y}=5,998+0,311 \mathrm{X}_{1}+0,424 \mathrm{X}_{2}+$ $0,818 \mathrm{X}_{3}+\mathrm{e} \ldots(1)$

Keterangan :

$\mathrm{Y}=$ Kualitas Laporan Keuangan Pemerintah Daerah

$\mathrm{X} 1=$ Pengawasan Intern 


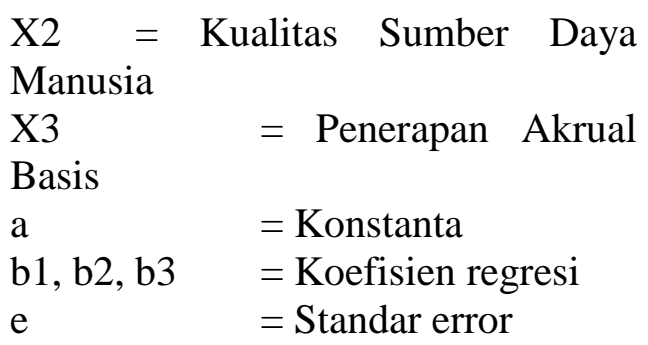

Dari persamaan di atas dapat dijelaskan bahwa :

1) Nilai konstanta sebesar 5,998 mengindikasikan bahwa jika variabel independen (pengawasan intern, kualitas sumber daya manusia dan penerapan akrual basis) adalah nol maka kualitas laporan keuangan pemerintah daerah akan terjadi sebesar 5,998.

2) Koefisien regresi variabel pengawasan intern $\left(\mathrm{X}_{1}\right)$ sebesar 0,311 mengindikasikan bahwa setiap kenaikan satu satuan variabel pengawasan intern akan meningkatkan kualitas laporan keuangan pemerintah daerah sebesar 0,311.

3) Koefisien regresi variabel kualitas sumber daya manusia $\left(\mathrm{X}_{2}\right)$ sebesar 0,424 mengindikasikan bahwa setiap kenaikan satu satuan variabel kualitas sumber daya manusia akan meningkatkan kualitas laporan keuangan pemerintah daerah sebesar 0,424.

4) Koefisien regresi variabel penerapan akrual basis $\left(\mathrm{X}_{3}\right)$ sebesar 0,818 mengindikasikan bahwa setiap kenaikan satu satuan variabel penerapan akrual basis akan meningkatkan kualitas laporan keuangan pemerintah daerah sebesar 0,818 . $\underline{\text { Pembahasan }}$

Penelitian mengenai hal-hal apa saja yang memengaruhi kualitas laporan keuangan pemerintah daerah, yang melibatkan pengaruh variabel bebas (pengawasan intern, kualitas sumber daya manusia dan penerapan akrual basis) terhadap variabel independen (kualitas laporan keuangan pemerintah daerah), dapat dibuat pembahasan sebagai berikut:

1. Pengaruh Pengawasan intern terhadap kualitas laporan keuangan pemerintah daerah.

Hipotesis pertama yang diajukan pada penelitian ini adalah bahwa pengawasan intern berpengaruh terhadap kualitas laporan keuangan pemerintah daerah. Artinya, dengan pengawasan interrn yang optimal maka akan meningkatkan kualitas laporan keuangan pemerintah daerah. Berdasarkan hasil analisis menunjukkan, pengawasan intern berpengaruh positif dan signifikan terhadap kualitas laporan keuangan pemerintah daerah. Hasil ini menujukkan bahwa responden penelitian berpendapat dengan pengawasan intern yang optimal maka akan berimplikasi terhadap peningkatan kualitas kualitas laporan keuangan pemerintah daerah. Pengawasan intern telah memenuhi fungsinya dalam hal memberikan keyakinan memadai tentang keandalan laporan keuangan, kepatuhan terhadap hukum dan perundang-undangan dan efektifitas dan efisiensi operasi. Hasil penelitian ini mendukung hasil penelitian sebelumnya yaitu Ponamon (2013). Hasil penelitiannya menyatakan bahwa pengawasan intern 
berpengaruh positif terhadap kualitas laporan keuangan pemerintah daerah kota Manado.

Pengawasan intern juga menjadi salah satu faktor signifikan yang memengaruhi laporan keuangan pemerintah daerah sejalan dengan temuan BPK-RI atas kurangnya pengawasan intern yang mengindikasikan terjadinya kebocoran dan ketidakpatuhan terhadap perundang-undangan sehingga BPK memberikan opini Tidak Wajar (TW) bahkan Tidak Memberikan Pendapat (TMP) atas sebagian besar Laporan Keuangan Pemerintah Daerah (LKPD) pemerintah kota/daerah di Indonesia. Untuk LKPD kota Makassar, BPK memberikan opini WDP selama lima tahun berturut-turut (2009-2014). Hal ini mengindikasikan bahwa pengawasan intern di pemerintahan daerah kota Makassar bisa dikategorikan cukup baik walaupun belum biasa dikatakan baik sekali karena belum mendapat opini Wajar Tanpa Pengecualian (WTP). Semakin pengawasan intern pemerintah daerah maka akan berdampak pada peningkatan kualitas laporan keuangan pemerintah daerah.

Menjaga integritas data yang dimiliki agar tetap akurat, konsisten dan mencerminkan kualitas data merupakan tanggung jawab suatu organisasi dalam melaksanakan pengendalian internal terhadap entitasnya tersebut. Selain itu, Ketepatan input dan posting data keuangan merupakan hal yang sangat mendasar dalam menjamin kualitas penyajian laporan pertanggungjawaban suatu organisasi. Adanya sistem otorisasi dan pembatasan akses terhadap segala bentuk pemrosesan transaksi oleh pihak yang berwenang akan menjamin data keuangan dalam suatu organisasi tetap aman. Dilaksanakannya perumusan dalam penyusunan kebijakan yang sehat tentang pengawasan intern sangat diperlukan sebagai pendukung penerapan pengawasan intern dalam suatu organisasi. Pada akhirnya, setiap alat ukur dari pengawasan intern yang dilaksanakan secara optimal akan berimplikasi pada peningkatan kualitas penyajian laporan pertanggungjawaban suatu entitas yang dalam hal ini pada Satuan Kerja Perangkat Daerah (SKPD) kota Makassar.

2. Pengaruh kualitas sumber daya manusia terhadap kualitas laporan keuangan pemerintah daerah

Hipotesis kedua yang diajukan pada penelitian ini adalah bahwa kualitas sumber daya manusia berpengaruh terhadap kualitas laporan keuangan pemerintah daerah. Artinya, sumber daya manusia yang memiliki kompetensi di bidang akuntansi atau keuangan yang mengisi posisi atau jabatan disebuah instansi pemerintahan maka akan meningkatkan kualitas pembuatan laporan keuangan pemerintah daerah. Berdasarkan hasil analisis menunjukkan, kualitas sumber daya manusia berpengaruh positif dan signifikan terhadap kualitas laporan keuangan pemerintah daerah. Hasil ini menujukkan bahwa responden pada umumnya menyadari bahwa sumber daya manusia yang memiliki kompetensi dalam mengisi posisi dan jabatan pada bidang pengelolaan keuangan suatu instansi, maka akan 
berimplikasi terhadap peningkatan kualitas kualitas laporan keuangan pemerintah daerah yang dihasilkan. Hasil penelitian ini mendukung hasil penelitian sebelumnya yaitu Sukmaningrum (2013) , Novitasari (2014) dan Sinarwati et all (2014). Hasil penelitian mereka mennyatakan bahwa kualitas sumber daya manusia berpengaruh positif terhadap kualitas laporan keuangan pemerintah daerah.

Sumber daya manusia yang memiliki kompetensi di bidang keahliannya masing-masing akan dapat menjalankan peranan dan fungsinya dalam merencanakan, melaksanakan, dan mengendalikan kegiatan suatu organisasi dengan baik guna mencapai tujuan organisasi kedepannya. Kompetensi sumber daya manusia dapat dijadikan sebagai indikator serta alat ukur suatu pemerintahan dalam menilai seberapa efektif dan efisien pelaksanakan tugas dan fungsi oleh sumber daya manusia dalam hal penyelenggaraan pemerintahan. Dengan adanya sumber daya manusia yang memiliki kompetensi khususnya dibidang akuntansi atau keuangan akan dapat mendorong terwujudnya penyajian laporan keuangan pemerintah yang berkualitas sehingga meningkatkan ketepatan dan akuntabilitas pengelolaan keuangan pemerintah daerah.

Sumber daya manusia yang memiliki kecakapan dan keterampilan dalam menganalisis transaksi dan mengolah laporan keuangan dengan berpedoman pada Sistem Akuntansi Pemerintahan (SAP) akan mampu menyajikan laporan keuangan yang memenuhi karakteristik kualitatif (relevan, andal, dapat dibandingkan dan dapat dipahami). Selain itu, uraian tugas dan wewenang pegawai (sumber daya manusia) yang jelas akan mendorong penyelesaian tugas secara optimal dan tepat waktu. Keikutsertaan pegawai dalam sebuah pendidikan dan Pelatihan (Diklat) pegawai mengenai pengelolaan keuangan daerah akan membantu dalam penyelesaian tugas sehari-hari dan membantu dalam memahami peraturan-peraturan baru mengenai pengelolaan keuangan daerah. Dengan demikian jika telah memenuhi unsur kualitatif (kompetensi) dan kuantitas (jumlah) yang memadai maka akan berdampak pada peningkatan kualitas dalam penyajian laporan keuangan pemerintah daerah di kota Makassar

3. Pengaruh Penerapan Akrual Basis terhadap kualitas laporan keuangan pemerintah daerah

Hipotesis ketiga yang diajukan pada penelitian ini adalah bahwa penerapan akrual basis berpengaruh terhadap kualitas laporan keuangan pemerintah daerah. Artinya dengan menerapkan basis akrual setiap Satuan Kerja Perangkat Daerah yang terdapat di kota Makassar, maka akan meningkatkan kualitas laporan keuangan pemerintah daerah. Hasil penelitian ini menunjukkan variable yang berpengaruh signifikan dikarenakan standar akuntansi berbasis akrual merupakan standar yang dapat dijadikan acuan untuk menghasilkan keterandalan pelaporan keuangan pemerintah daerah yang lebih berkualitas dibandingkan standar yang lama. Berdasarkan hasil uji analisis 
deskriptif penelitian ini, sebagian besar responden sepakat untuk menyatakan bahwa pemerintah daerah mempunyai/memiliki keinginan dan kemauan untuk mencapai hasil kerja yang baik dengan pembangunan SAP sebagai sarana mendukung optimasi bidang tugas pemerintahan daerah. Hal ini menunjukkan dengan menggunakan SAP yang baik maka akan meningkatkan kualitas laporan keuangan pemerintah daerah.

Hasil dalam penelitin ini sejalan dengan penelitian yang dilakukan oleh Christanti (2015) yang menemukan bahwa akuntansi pemerintahan berbasis akrual berpengaruh terhadap kualitas laporan keuangan daerah pemerintahan Provinsi Jawa Barat. Hal ini dikarenakan pemerintah melakukan ketentuan, menyelenggarakan akuntansi dan pelaporan keuangan dengan baik sehingga mampu meningkatkan keterandalan laporan keuangan. Meskipun dari pengamatan peniliti ternyata di beberapa SKPD yang terdapat di kota Makassar masih banyak pegawai yang belum mengerti bahkan tidak mengerti tentang Standar Akuntansi Pemerintahan (SAP) berbasis akrual namun seharusnya dengan keterbatasan pengetahuan para pegawai tentang SAP berbasis akrual, para pegawai harus diberikan pelatihan terhadap pelaporan keuangan lebih sering lagi. Agar semua pegawai memperoleh pengetahuan yang lebih tentang SAP berbasis akrual dan dapat menjalankan tugas mereka dengan baik. Sehingga, menghasilkan kualitas laporan keuangan pemerintah daerah yang baik terkhusus pada pemerintah kota Makassar.

\section{KESIMPULAN}

Penelitian ini memiliki tujuan untuk mengetahui pengaruh tiga variabel independen yaitu pengawasan intern, kualitas sumber daya manusia, dan penerapan akrual basis terhadap variabel dependen yaitu kualitas laporan keuangan pemerintah daerah.

Berdasarkan pada data yang dikumpulkan dan pengujian yang telah dilakukan maka dapat diambil kesimpulan sebagai berikut:

1. Pengawasan intern berpengaruh positif dan signifikan terhadap kualitas laporan keuangan pemerintah daerah. Hal ini berarti bahwa kegiatan pengawasan internal telah dilakukan pada SKPD Pemerintah Kota Makassar, sehingga dengan diterapkannya pengawasan intern secara efektif dan efisien dapat meningkatkan kulitas laporan keuangan pemerintah kota Makassar.

2. Kualitas sumber daya manusia berpengaruh positif dan signifikan terhadap kualitas laporan keuangan pemerintah daerah. Hal ini berarti bahwa sumber daya manusia yang memiliki kompetensi di bidang keahliannya masing-masing akan dapat menjalankan peranan dan fungsinya dalam merencanakan, melaksanakan, dan mengendalikan kegiatan suatu organisasi dengan baik guna mencapai tujuan, yakni meningkatnya kualitas laporan 
keuangan pemerintah daerah Kota Makassar.

3. Penerapan akrual basis berpengaruh positif dan signifikan terhadap kualitas laporan keuangan pemerintah daerah, $\mathrm{Hal}$ ini berarti bahwa dengan menerapkan basis akrual setiap Satuan Kerja Perangkat Daerah yang terdapat di kota Makassar, maka akan meningkatkan kualitas laporan keuangan pemerintah daerah.

4. Pengawasan intern, kualitas sumber daya manusia, dan penerapan akrual basis berpengaruh secara positif dan signifikan terhadap kualitas laporan keuangan pemerintah daerah. Hasil penelitian ini menunjukkan bahwa dengan menerapkan pengawasan intern yang efektif dan efisien, sumber daya manusia yang memiliki kompetensi dalam pengelolaan keuangan daerah serta penerapan akrual basis yang baik akan mampu meningkatkan kualitas laporan keuangan pemerintah daerah.

\section{DAFTAR PUSTAKA}

Adisasmita. H.R., 2005. Dasar-dasar Ekonomi Wilayah. Jakarta: Graha Ilmu.

Bastian, Indra, 2010. Akuntansi Sektor Publik: Suatu

Pengantar Edisi III, Jakarta: Erlangga.

\begin{tabular}{|c|c|c|}
\hline Badan & Pemeriksa & Keuangan \\
\hline & Republik & Indonesia, \\
\hline & Penyerahan & Hasil \\
\hline & Pemeriksaan & Laporan \\
\hline & $\begin{array}{l}\text { Keuangan } \\
\text { Daerah }\end{array}$ & Pemerintah \\
\hline
\end{tabular}

http://makassar.bpk.go.id/?p= 9136 ( 24 Agustus)

Badan Pemeriksa Keuangan Republik Indonesia, Ikhtisar Hasil Pemeriksaan Semester I Tahun 2014. Jakarta, Mei 2015. www.bpk.go.id (20 Agustus 2015)

Cristianti, Dianne Natalie, Pengaruh Akuntansi Berbasis Akrual dan Sistem Pengendalian Intern terhadap Kualitas Laporan Keuangan, (studi pada Biro Keuangan Setda Pemerintah Provinsi Jawa Barat) 2014.

COSO. Internal Control-Integrated Framework. 1992. www.coso.org (25 Agustus 2015).

Damayanti, Ayu, Ratna. 2013. Akuntansi Akrual Dan Penerapannya Di Sektor Publik: Sebuah Agenda Pembaruan

Halim, Abdul. Akuntansi Sektor Publik Akuntansi Keuangan Daerah. Edisi Revisi; Jakarta: Salemba Empat, 2007.

Huda, Ni'matul. Pengawasan Pusat Terhadap Daerah Dalam Penyelenggaraan

Pemerintahan Daerah. Yogyakarta: FH UII Press, 2007.

Ihsanti, Emilda, Pengaruh Kompetensi Sumber Daya Manusia dan Penerapan Sistem Akuntansi Keuangan Daerah Terhadap Kualitas Laporan Keuangan Daerah (studi empiris pada skpd kab. lima puluh kota) 2014 Indriasari, Desi. 2008. Pengaruh Kapasitas Sumber Daya Manusia, Pemanfaatan 
Teknologi Informasi dan Sistem Pengendalian Intern terhadap Nilai Informasi Pelaporan Keuangan Pemerintah Daerah.

Irawan, Surya, Arif. 2013. Analisis Pengaruh Implementasi Akuntansi Pemerintahan Berbasis Akrual (APBA) atas Entitas Pelaporan Keuangan Pemerintah.

Keputusan Menteri Keuangan nomor 308/KMK/2002 terntang

Komite Standar Akuntansi Pemerintahan (KSAP)".

Keputusan Menteri Keuangan Republik Indonesia Nomor 308/Kmk.012/ 2002 Tentang Komite Standar Akuntansi Pemerintah Pusat Dan Daerah".

Kiswara, Endang, 2011, Nilai Relevan Dan Reliabilitas Kegunaan-Keputusan

InformasiAkuntansi Menurut Sfac No. 2 Dalam Penyajian Laporan Keuangan DenganMetode-Metode

Pembebanan Pajak Penghasilan Berbeda. PhD thesis, Universitas Diponegoro, Semarang.

Kusuma, Yudha, Indra. 2013. Analisis Faktor-Faktor yang Mempengaruhi Tingkat Penerapan Akuntansi Akrual pada Pemerintah.

Mardiasmo, "Elaborasi Reformasi Akuntansi Sektor Publik: Telaah Kritis Terhadap Upaya Aktualisasi Kebutuhan Sistem Akuntansi Keuangan Pemerintah Daerah". Jurnal Akuntansi Auditing Indonesia Vol. 6 No. 1 (Juli 2002).
Mardiasmo, 2009.Akuntansi Sektor Publik. Yogyakarta: Penerbit ANDI.

Mardiasmo. 2002. Otonomi Daerah sebagai Upaya Memperkokoh Basis Perekonomian Daerah. Jurnal Otonomi Daerah 1 (4): $1-14$.

Mulyadi. 2000. Akuntansi Biaya Edisi 5. Yogyakarta: Aditya Media.

Peraturan Menteri Dalam Negeri Nomor 13 Tahun 2006 tentang Pedoman Pengelolaan Keuangan Daerah". Nomor 59 Tahun 2007 tentang Perubahan Atas Peraturan Menteri Dalam Negeri Nommor 13 Tahun 2006 tentang Pedoman Pengelolaan Keuangan Daerah".

Peraturan Pemerintah Nomor 58 Tahun $2005 \quad$ Tentang Pengelolaan Keuangan Daerah Nomor 60 Tahun 2008 Tentang Sistem Pengendalian Internal Pemerintah". Nomor 71 Tahun 2010 Tentang Standar Akuntansi Pemerintahan".

Permadi, Angga Dwi, Pengaruh Sistem Akuntansi Keuangan Pemerintah Daerah terhadap Kualitas Laporan Keuangan Pemerintah Daerah (studi pada Dinas Bina Marga Provinsi Jawa Barat) 2013

Sari, Novita, Lusi. Pengaruh kapasitas sumber daya manusia dan peran auditor internal Pemerintah terhadap kualitas laporan keuangan Pemerintah daerah (studi 
empiris pada satuan kerja perangkat daerah kabupaten kerinci) 2014.

Sekaran, Uma. Research Methods For Business: A Skill Building Aproach. New York-USA: John Wiley and Sons, Inc, 2003.

Sugiyono. Metode Penelitian Kuantitatif, Kualitatif dan $R \& D$. Bandung: Alfabeta, 2009.

Sujarweni, V.W. 2014, SPSS Untuk Penelitian, Pustaka Baru: Jakarta

Supomo, B. Dan N. Indriantoro, 2014, Metodologi Penelitian Bisnis: Untuk Akuntansi dan Manajemen. Penerbit BPFE, Yogyakarta.

Sukmaningrum, Tantriani. "Analisis Faktor-Faktor yang Mempengaruhi Kualitas Informasi Laporan Keuangan Pemerintah Daerah (Studi Empiris pada Pemerintah Kabupaten dan Kota Semarang)". Jurnal Fakultas Ekonomika dan Bisnis, Universitas Diponegoro, Semarang (2012).

Undang-Undang Republik Indonesia Nomor 15 Tahun 2004 tentang Pemeriksaan Pengelolaan dan Tanggung Jawab Keuangan Negara. Nomor 32 Tahun 2004 tentang Pemerintah Daerah. Nomor 15 Tahun 2006 tentang Badan Pemeriksa Keuangan. 
